\title{
Research on the Design and Practice Teaching of Transportation Courses under the Guidance of "The Belt and Road" Strategy
}

\author{
Min JI, Bolin JIANG, Anping XU, Hongli LI \\ Chongqing Vocational Institute of Engineering \\ No.1 Nanbei Avenue, Bingjiang new town, Jiangjin district, Chongqing, China 402260
}

\begin{abstract}
Based on the guidance of the national "The Belt and Road" strategy and the implementation of integrating production with education in vocational education, this paper has established and improved the "Luban college" transportation course system in China-Africa cooperation project in Tanzania in order to complement the gap in the development and use of the international course system in vocational education, and designed a curriculum system including theoretical and practical courses in detail based on the actual demand of the Tanzanian cooperative enterprises for technical talents in infrastructure construction, and reasonable arranging courses and class hours, striving to carry out the practice and application in the project promotion.
\end{abstract}

Keywords-The Belt and Road; Luban College; Course System; Transportation Infrastructure Construction

\section{INTRODUCTION}

"The Belt and Road" strategy is an inherent requirement of the reform of the global governance system and a new idea and new plan for improving the global governance system. Transportation is a basic, leading and strategic industry in the national economy. As a vocational educators, we actively use the education and teaching of civil engineering related courses as a carrier, take Tanzania as a pilot and starting point, and seek cooperation with countries along the route, steadily promote the implementation of education and teaching, grasp the results of cultural integration and implement the national strategy, which has far-reaching strategic significance for China's modernization and its leadership in the world. We adhere to the concept of openness, coordination, cooperation, innovation and development, integrate resources, seek coordinated development of vocational education and industry, further lead the vocational education to echo "The Belt and Road", expand vocational education exchanges and cooperation among the countries and regions along the route, enhance internationalization of vocational colleges, and help enterprises to 'go out'.

\section{RESEARCH ON THE STRATEGIC BACKGROUND OF "THE BELT AND ROAD"}

Since "The Belt and Road" initiative and strategy were put forward, vocational education cooperation with Central African countries along the route has gradually been put on the agenda. In 2015, the China-ASEAN Vocational Education Exhibition Forum was held in Nanning and kicked off the Belt "Cooperating and cultivating talents and boosting "The Belt and Road"' is the central topic of the forum. This event is also one of the series activities of the 12th China-ASEAN Expo. The purpose of the forum is to build a platform for international cooperation in vocational education and strengthen cooperation between China and ASEAN countries in the field of vocational education; "The Belt and Road" Production and Education Coordination Summit was held in Beijing in October 2016. It initiated the initiative and call of the establishment of the Production and Education Coordination Alliance, which further provides an opportunity and a hotbed for promoting the in-depth development of production and education coordination in countries along "The Belt and Road"; In June of the following year, the "Opening Ceremony of the Silk Road Education Cooperation and Exchange Conference under the Silk Road International Expo in 2017" was grandly opened in Xi'an, and "The Belt and Road" vocational education alliance was formally established.

At the same time, we can also see that the motion was proposed in 2015 and the initiative was launched in 2016, on June 9, 2017, "The Belt and Road" Production and Education Coordination Alliance was formally established in the oriental starting port of the "Maritime Silk Road" - Ningbo, Zhejiang, and 76 vocational colleges across the country and 13 leading enterprises in different industries, including AVIC International, and other industry organizations such as China Education Association for International Exchange, Nonferrous Metals Industry Association and National Semiconductor Industry Alliance joined the alliance. It is true that in terms of quantity, there are more and more "The Belt and Road" international cooperation platforms. However, from the operational level, the depth of communication between countries along "The Belt and Road" using international cooperation platforms is still insufficient. Much cooperation remains limited to short-term visits and low-level cultural and

Project support: Chongqing Municipal Education Commission Higher Education Teaching Reform Research Funding Project (Project No.: 183238), Chongqing Vocational Institute of Engineering Education and Teaching Reform Research Project Funding Project (Project No.: JG171002). 
technical exchanges. The form of cooperation is still inseparable from lectures and interviews. In addition, there are still many problems in the cooperation in running schools, for example, the development capability of collaborative enterprises needs to be improved, the development efforts of internationalized high-level courses are not enough, there is a gap in the development and use of international course systems, and the international outlook of the faculty needs to be broadened.

\section{SIGNIFICANCE OF THE RESEARCH ON "THE BELT AND} ROAD" TRANSPORTATION COURSE SYSTEM DEVELOPMENT

For the construction of "The Belt and Road", the development of the transportation industry is particularly important. For the development of "The Belt and Road" Vocational Education Alliance and the in-depth implementation of the integration of production and education, "The Belt and Road" transportation professional course system should be constructed, and then the course system can be applied in practical teaching. The implementation and continuous modification in the "Luban College" project in Tanzania is not only the time requirement of giving play to the leading function of transportation, but also the practical need of serving in-depth integration of vocational education and teaching in the construction of "The Belt and Road". "The Belt and Road" transportation course design includes domestic construction, international construction and cultural construction in a broad sense. Among them, in cultural dimension, it should focus on enriching China's international communication channels with traffic as a carrier, integrate the cultural customs of the countries along "The Belt and Road", and use China's modern transportation system as a business card for China's modernization, interpret and convey the concept of China's modern transportation culture and display the national image by shaping and spreading the image of China as a transportation power. In a narrow sense, we urgently need to build a specific professional course system, with the "Luban College" as a pilot, combined with the actual needs of Tanzanian cooperative enterprises, formulate relevant theoretical and practical training courses, rationally arrange courses and class hours, and actually practice the strategy of "The Belt and Road".
At the beginning of 2018, Chongqing Vocational Institute of Engineering, the research unit of this paper and the Chinese-funded enterprise in Tanzania -- United Construction International Co., Ltd. jointly launched "Luban College". The main purpose of "Luban College" was to cultivate outstanding Tanzanian employees in the cooperative units, pass on China's mature infrastructure construction technology to the Tanzanian personnel, especially the road construction, roads, tunnels, municipalities and other infrastructure construction technologies related to the national economy and people's livelihood. The construction of the course system of "Luban College" needs to be set up around the local social development of Tanzania and the needs of industrial enterprises, such as road engineering measurement technology, bridge construction technology, reading and drawing of bridge structure engineering drawings, etc., which can greatly meet the needs for local transportation talents. The research and implementation of transportation course design and practical teaching, on the one hand, shares China's advanced infrastructure construction technology and excellent vocational education theories and methods with Tanzanian technical personnel, and opens a window for more countries to understand China's road and bridge construction level and higher education level, and also sets up a training and practice base for our students overseas, which also enhances our vocational education level and the international perspective of technical personnel, and also provides reference for similar peer colleges to carry out China-foreign cooperative projects, such as the design and practical teaching of transportation vocational education courses under the background of "The Belt and Road".

\section{CONSTRUCTION AND RESEARCH OF TRANSPORTATION COURSE SYSTEM}

The project set up Luban College in Dar-es-Salaam, Tanzania. Our school teachers trained Tanzanian road and bridge construction managers at Luban College to train Tanzanian middle and senior managers in road construction management for Tanzania. The training period is 3 months per period. The course system is constructed as follows: 
TABLE I

COURSE SYSTEM

\begin{tabular}{|c|c|c|c|c|c|}
\hline $\begin{array}{c}\text { Serial } \\
\text { No. }\end{array}$ & $\begin{array}{l}\text { Time } \\
\text { (day) }\end{array}$ & Courses & Main contents & Hours & Remarks \\
\hline 1 & 15 & $\begin{array}{c}\text { Road engineering } \\
\text { measurement } \\
\text { technology }\end{array}$ & $\begin{array}{l}\text { 1. Leveling instruments and their use } \\
\quad \text { And calculation of results; } \\
\text { 2. Use of the total station; } \\
\text { 3. Traverse survey; } \\
\text { 4. Road engineering topographic map } \\
\text { mapping and application; } \\
\text { 5.Construction stakeout and } \\
\text { construction control measurements; } \\
\text { 6. Completion measurement and } \\
\text { deformation measurement. }\end{array}$ & 120 & $\begin{array}{l}\text { The teaching time and } \\
\text { content of each chapter } \\
\text { can be adjusted according } \\
\text { to the students' } \\
\text { knowledge. Focus on the } \\
\text { use and measurement } \\
\text { methods of measuring } \\
\text { instruments }\end{array}$ \\
\hline 2 & 25 & Road engineering & $\begin{array}{l}\text { 1.Flat, vertical and horizontal design of } \\
\text { the route, plane intersection and three } \\
\text { dimensional cross design; } \\
\text { 2. Route selection and alignment; Field } \\
\text { work of highway survey; } \\
\text { 3.Composition of roadbed and } \\
\text { pavement; } \\
\text { 4. Roadbed engineering materials; } \\
\text { 5. Pavement engineering materials; } \\
\text { 6.Construction technology and quality } \\
\text { inspection of roadbed and pavement; } \\
\text { 7.Culvert and retaining wall } \\
\text { construction; } \\
\text { 8.Characteristics and application of } \\
\text { common road construction machinery. }\end{array}$ & 200 & $\begin{array}{l}\text { The teaching time of each } \\
\text { chapter can be adjusted } \\
\text { according to the students' } \\
\text { knowledge. Focus on road } \\
\text { construction, inspection } \\
\text { and management }\end{array}$ \\
\hline 3 & 2 & $\begin{array}{l}\text { Cognition of } \\
\text { bridge structure } \\
\text { and reading and } \\
\text { drawing of } \\
\text { engineering } \\
\text { drawings }\end{array}$ & $\begin{array}{l}\text { 1.Understand the basic composition of } \\
\text { the bridge; } \\
\text { 2.Understand the type of structure of the } \\
\text { bridge; } \\
\text { 3.Cognition of bridge structure diagram; } \\
\text { 4.Using CAD to draw bridge drawings. }\end{array}$ & 16 & $\begin{array}{l}\text { The teaching time and } \\
\text { content of each chapter } \\
\text { can be adjusted according } \\
\text { to the students' } \\
\text { knowledge. Focus on the } \\
\text { method of reading and } \\
\text { drawing of engineering } \\
\text { drawings }\end{array}$ \\
\hline 4 & 3 & $\begin{array}{c}\text { Bridge } \\
\text { construction } \\
\text { technology }\end{array}$ & $\begin{array}{l}\text { 1.Taking Shibanpo Yangtze River } \\
\text { Bridge as an example to introduce the } \\
\text { construction technology of cantilever; } \\
\text { 2.Taking Wushan Yangtze River } \\
\text { Bridgeas an example to introduce the } \\
\text { construction technology of concrete- } \\
\text { filled steel tube; } \\
\text { 3.Taking Sutong Bridge as an example } \\
\text { to introduce the construction technology } \\
\text { of cable-stayed bridge; } \\
\text { 4.Taking Hangzhou Bay Sea-Crossing } \\
\text { Bridge as an example to introduce } \\
\text { prefabricated prestress construction } \\
\text { technology; } \\
\text { 5.Cast-in-place construction technology. }\end{array}$ & 24 & $\begin{array}{l}\text { The teaching time and } \\
\text { content of each chapter } \\
\text { can be adjusted according } \\
\text { to the students' } \\
\text { knowledge. }\end{array}$ \\
\hline
\end{tabular}


Table I, cont

\begin{tabular}{|c|c|c|c|c|c|}
\hline 5 & 2 & $\begin{array}{l}\text { Bridge inspection } \\
\text { and maintenance } \\
\text { reinforcement }\end{array}$ & $\begin{array}{l}\text { 1.Understand the bridge detection and } \\
\text { measurement technology and bridge } \\
\text { inspection methods; } \\
\text { 2.Understand the bridge static load and } \\
\text { dynamic load test, non-destructive } \\
\text { testing technology; } \\
\text { 3.Bridge health monitoring, } \\
\text { maintenance and reinforcement } \\
\text { technology. }\end{array}$ & 16 & $\begin{array}{l}\text { The teaching time and } \\
\text { content of each chapter } \\
\text { can be adjusted according } \\
\text { to the students' } \\
\text { knowledge. Focus on } \\
\text { detection technology }\end{array}$ \\
\hline 6 & 2 & $\begin{array}{l}\text { Construction } \\
\text { technology of } \\
\text { building trades }\end{array}$ & $\begin{array}{l}\text { 1.Masonry construction technology } \\
\text { 2.Plaster construction technology } \\
\text { 3.Steel bar construction technology } \\
\text { 4. Scaffolding construction technology } \\
\text { 5. Concrete construction technology }\end{array}$ & 16 & $\begin{array}{l}\text { The teaching time and } \\
\text { content of each chapter } \\
\text { can be adjusted according } \\
\text { to the students' } \\
\text { knowledge. Focus on } \\
\text { operating standards and } \\
\text { quality assessment }\end{array}$ \\
\hline 7 & 5 & $\begin{array}{l}\text { Organization } \\
\text { management in } \\
\text { construction }\end{array}$ & $\begin{array}{l}\text { 1.Basic principles of construction } \\
\text { organization; } \\
\text { 2.Preparation of construction scheme } \\
\text { 3.Preparation of construction schedule } \\
\text { plan } \\
\text { 4.Construction plane layout } \\
\text { 5.Construction data management }\end{array}$ & 40 & $\begin{array}{l}\text { The teaching time and } \\
\text { content of each chapter } \\
\text { can be adjusted according } \\
\text { to the students' } \\
\text { knowledge. }\end{array}$ \\
\hline 8 & 4 & $\begin{array}{l}\text { Engineering } \\
\text { Software } \\
\text { Application }\end{array}$ & $\begin{array}{l}\text { 1.BIM basic technology } \\
\text { 2.Basic methods and skills of CAD } \\
\text { mapping; } \\
\text { 3. Read the construction drawings of } \\
\text { roads and tunnels, bridges and culverts, } \\
\text { and draw engineering drawings of roads, } \\
\text { bridges and tunnels. }\end{array}$ & 24 & $\begin{array}{l}\text { The teaching time and } \\
\text { content of each chapter } \\
\text { can be adjusted according } \\
\text { to the students' } \\
\text { knowledge. Focus on } \\
\text { CAD drawing and } \\
\text { recognizing methods }\end{array}$ \\
\hline 9 & 2 & $\begin{array}{l}\text { Site practice } \\
\text { learning }\end{array}$ & $\begin{array}{l}\text { Construction technology of roads and } \\
\text { bridges and management of on-site } \\
\text { personnel, equipment, safety and so on. }\end{array}$ & 16 & $\begin{array}{l}\text { The time and content of } \\
\text { each chapter can be } \\
\text { adjusted according to the } \\
\text { students' knowledge. }\end{array}$ \\
\hline Total & 60 & & & 480 & \\
\hline
\end{tabular}

\section{CONCLUSION}

Under the guidance of "The Belt and Road" strategy, the transportation courses are designed with "post ability cultivation as the main line", highlighting "actual and practical" and establishing a course system that is compatible with the training objectives. The course content highlights the improvement of training personnel's knowledge and training of practical and operational skills. Through training, the trainees can further understand the knowledge of reading and drawing of engineering drawings, measurement technology, construction technology, testing technology, software application, organization management, etc., improve the knowledge and management level of road and bridge construction technology. It serves the local middle and senior managers of road and bridge construction in Tanzania.

\section{REFERENCES}

[1] Liping CHEN The Thinking on "The Belt and Road" Sino-foreign Cooperative Education Brought by "Luban Workshop" [J]. Journal of Tianjin College of Commerce, 2017(4): 53-56.

[2] Baojing FENG. The Concept and Path of the Internationalization of Vocational Education in China from the Perspective of "The Belt and Road" [J]. China Vocational and Technical Education, 2016 (23): 67-71.

[3] Xiangfen CHEN. Research on the Training Mode of Collaborative Innovation Talents in Higher Vocational Colleges under the Background of "The Belt and Road" [J]. China Vocational and Technical Education, 2016 (4): 42-45

[4] Tiancong HAO. China's Vocational Education Serving "The Belt and Road": Experience and Challenges [J]. Exploring Education Development, 2017(17): 62-68.

[5] Lei ZHU Research on the Path Innovation of Higher Vocational Colleges to Help Enterprises "Go Global" under the Background of "The Belt and Road" Strategy [J]. China Vocational and Technical Education, 2016 (33): 106-110. 